\title{
Possible effects of pre-existing basement topography on thrust fault ramping
}

\author{
ANDREW SCHEDL* \\ Department of Geological Sciences, University of Michigan, Ann Arbor, MI 48109, U.S.A. \\ and \\ David V. WiLtschko \\ Centre for Tectonophysics, Texas A \& M University, College Station, TX 77843, U.S.A.
}

(Received 10 April 1985; accepted in revised form 2 June 1987)

\begin{abstract}
Finite-element models show that one way in which thrust ramps may arise is through the mechanical interaction between basement and overlying sediments. In the simplest case, shear coupling between a planar basement-sediment contact causes the differential stresses in the sediments to die out with depth and distance from the applied load. For such cases, curved thrust faults may result if the strength of the rock is exceeded. Basement topography may also affect the location and shape of ramps by acting as a stress concentrator, by producing a stress shadow and by changing principal stress orientations. Modeling suggests that whether or not these basement topographic features cause ramping will depend on the height and angularity of the feature as well as the rock types that overlie it.

Under the assumption of linear elasticity and for given boundary conditions, the Poisson's ratio plays an important role in determining the orientation and magnitude of the principal stresses. Calculations using experimentally measured Poisson's ratios predict that the earliest maximum compressive stress directions should be nearly vertical in the more cratonward portions of thrust belts. However, the stress directions which are inferred to have occurred earliest in this part of thrust belts are nearly horizontal. This suggests that non-elastic or ductile processes have an effect on the propagation of thrust faults.
\end{abstract}

\section{INTRODUCTION}

Published interpretations of subsurface data from thrust belts often show an association between normal faults which cut the basement-sediment contact and younger thrust ramps (Jacobeen \& Kanes 1974, Seguin 1982, Thomas 1982, St. Julien et al. 1983, Lille 1984, Lille \& Yosuf 1986, Skipp 1986, Schmidt et al. 1987). Generally, those ramps which do appear to be associated with basement normal faults are rooted at or near the corners of the footwall blocks. However, in most cases the exact location, fault orientation and height of such steps in the basement-sediment contact are speculative because of poor seismic data and lack of well control. Furthermore, other structures such as sedimentary heterogeneities or through-faulting of pre-existing folds could also produce thrust ramps (e.g. Wiltschko \& Eastman 1983).

One of the better documented examples of this relationship between basement normal faults and ramps is the Birmingham Anticlinorium (Thomas 1982). Stratigraphic data from wells and surface exposures show that there is an increase in the depth to basement of at least $4 \mathrm{~km}$ over a distance of $20 \mathrm{~km}$ going from northwest to southeast. This change in depth to basement is believed to be caused by a steep, down-to-the southeast basement normal fault beneath the large

\footnotetext{
* Present address: Department of Geology and Geophysics, Louisiana State University, Baton Rouge, LA 70803-4101, U.S.A sc 9:8-G
}

thrust ramp associated with the Birmingham Anticlinorium. This basement normal fault was first initiated during Eocambrian rifting. Changes in stratigraphic thicknesses across the present day anticlinorium suggest episodic movement along the basement normal fault during the Mid-Cambrian, Mid-Silurian and Early Mississippian extension (Fig. 1). This movement produced a drape fold over the normal fault. Later during early post-Pennsylvanian compression a thrust ramp formed beneath this older drape fold. This fold was then carried over the ramp to become the crest of the Birmingham Anticlinorium (Fig. 1). The thrust fault did not use the earlier normal fault as a detachment surface, but rather cuts across the earlier feature.

To explain this association between pre-existing basement normal faults and thrust faults, Wiltschko \& Eastman (1983) proposed that basement warps and basement faults produced stress concentrations in overlying sediments when the latter were stressed. However, because they used photoelasticity as their modeling technique, they could not consider the effects of gravity and geologically realistic elastic constants. Scaling these factors in materials appropriate for photoelasticity is difficult (see Hubbert 1937). Our purpose in this paper is to extend the results of Wiltschko \& Eastman (1983) by incorporating these variables, by examining the effects of different applied boundary conditions and by examining the effects of varying the size of the pre-existing basement topography.

Two other studies have dealt with the interaction 
a.

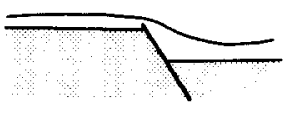

b.

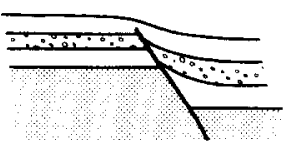

c.

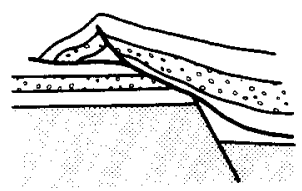

d.

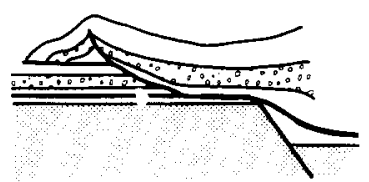

Fig. 1. Schematic history of the Birmingham Anticlinorium based on Thomas (1982). (a) Initiation of a basement normal fault in the Eocambrian. (b) The drape fold over the basement normal fault after Mid-Cambrian, Mid-Silurian and Early Mississippian movement. (c) Initiation of a thrust ramp in the early post-Pennsylvanian. (d) The transport of the thrust ramp cratonward by later faults.

between basement and overlying sediments. Advani et al. (1978) examined the relationship between basement normal faults and the development of fracture permeability and and accumulations of hydrocarbons. Müller and Hsü (1980) simulated the effects of a zone of detachment and overlying sediments, and explored the extent of detachment as a function of loading conditions. Our study differs from Advani et al. (1978) in that they treated basement as a boundary condition, whereas in this paper it is treated explicitly as an elastic medium. Also we studied a greater variety of applied boundary conditions and a greater range of Poisson's ratios. Unlike Müller and Hsü (1980), we have not included a weak layer between basement and sediments. We instead are more interested in the role of basement topography on the stress distribution in both basement and cover.

\section{METHODOLOGY}

The finite-element method is a technique for determining stresses, displacements and/or strains in a body with a specified rheology and boundary conditions (Bathe \& Wilson 1976, Zienkiewicz 1977). In this study stresses and displacements were calculated using the SAP-6 Finite-Element Program for linear elasticity and plane strain (SAP Technical Group 1979). We have assumed plane strain, and that rocks are linearly elastic over the time frame of interest (see also Hafner 1951, Hubbert 1951, Odé 1957, Sanford 1959, Cummings 1968, Muller and Pollard 1977, Segall 1984).

\section{Model configurations and boundary conditions}

Three basement geometries were considered: (a) no basement topography (Fig. 2); (b) a basement step one-ninth of the thickness of the sedimentary cover (Fig.

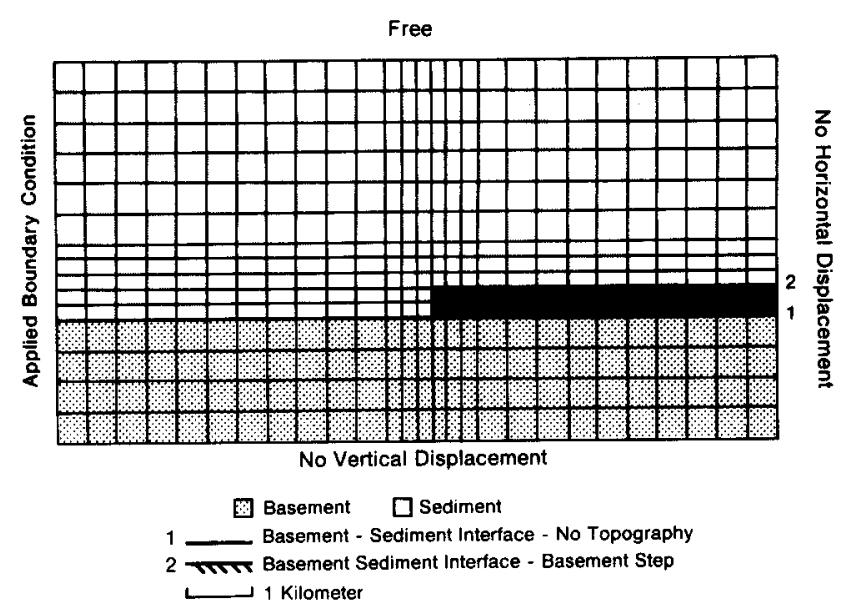

Fig. 2. Finite-element grid for the no-basement-step and smallbasement-step models. The grid consists of 405 eight-node elements. Boundary conditions are indicated for each surface. Basement is $2 \mathrm{~km}$ thick, cover is $4.5 \mathrm{~km}$ thick.

2); and (c) a basement step half the thickness of sedimentary cover (Fig. 3). In all models the right-hand vertical boundary had no horizontal movement, the upper boundary was free to move in any direction, and the lower boundary had no vertical displacement. The boundary condition on the left-hand side (what we have called the applied boundary condition) and basement step height were specified for each model (Figs. 2 and 3).

The finite-element grid in the no-basement-topography and small-basement-step geometries have 405 eight-node isoparametric elements (Fig. 2). The sedimentary package is $4.5 \mathrm{~km}$ thick and basement is 2.0 $\mathrm{km}$ thick. Boundary conditions were of three types: (a) a constant $15 \mathrm{~m}$ horizontal displacement in both basement and sediments (CDBS); (b) a constant $15 \mathrm{~m}$ horizontal displacement in sediments alone (CDS); and (c) a nearly constant stress applied to both basement and sediments (CS). The CDBS boundary condition corresponds to a rigid indentor. The CDS boundary condition simulates a purely 'thin-skinned' geometry. A CS boundary condition corresponds to the case where both basement and sediments are being deformed such as that expected near a compressional plate boundary. Each boundary condition described above should be viewed as an end-member case. None of these boundary conditions may be precisely reproduced in nature, but many natural systems contain elements of each.

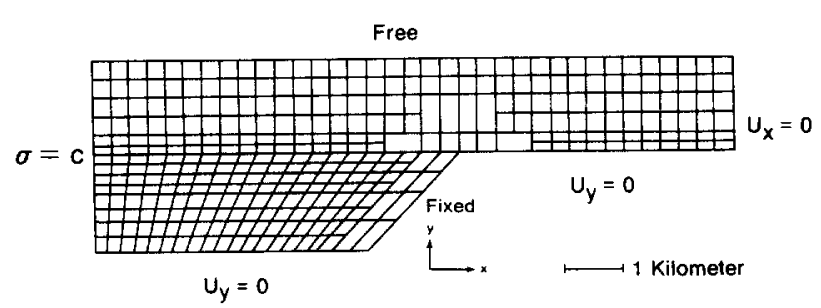

Fig. 3. Finite-element grid for the large-basement-step model containing 270 elements. The elements in the central region have eight nodes, elsewhere they have four nodes. Applied stress, $\sigma=c$; no horizontal displacement, $u_{x}=0$; no vertical displacement, $u_{y}=0$. 


\section{Differential Stresses \\ a. CDBS \\ $\mathrm{u}=15 \mathrm{~m}$ in both layers

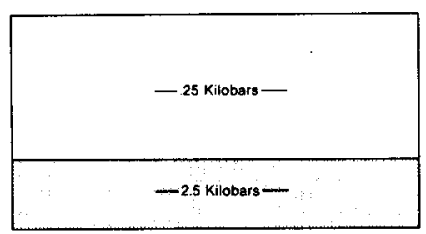 \\ Maximum Principal Compressive Stress Directions \\ b. CDS \\ $u=15 \mathrm{~m}$ in top layer
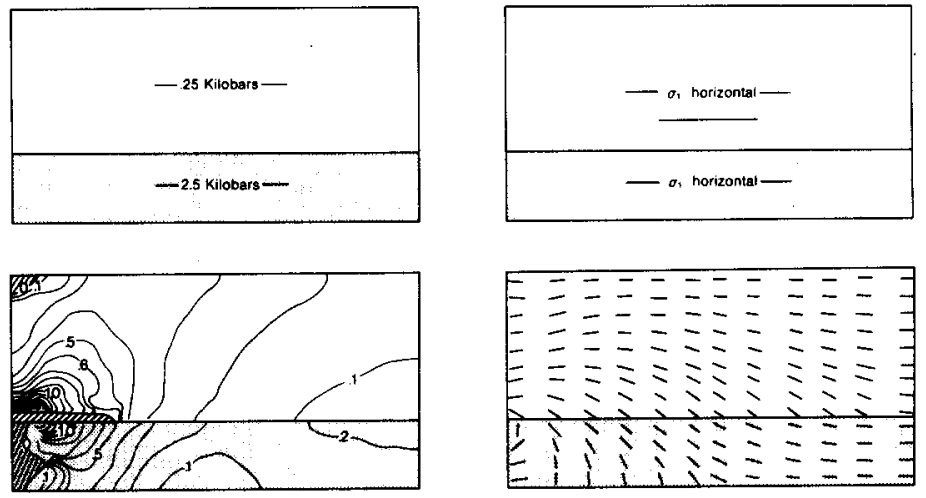 \\ c. CS

$$
\sigma=.5 \mathrm{~kb} \text { in both layers }
$$
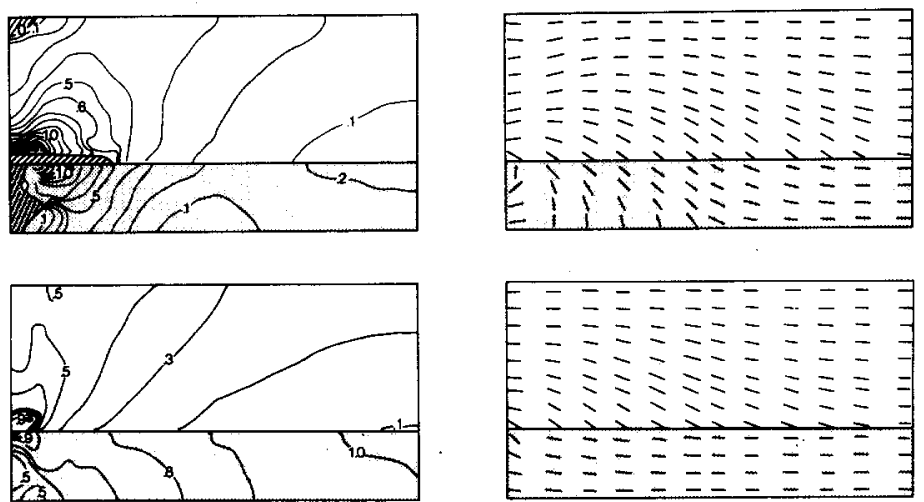 \\ Contour Interval .1 Kilobars

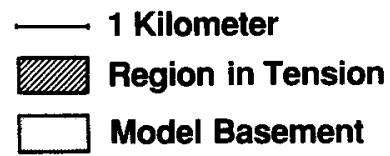

Fig. 4. No topography models, $v=0.499$. Differential stresses are contoured on the left-hand side of the figure and the corresponding maximum principal stress directions are shown on the right. (a) CDBS boundary condition; (b) CDS boundary condition; (c) CS boundary condition (see text).

The finite-element method only allows specification of nodal forces (not stresses), thus a CS boundary condition was produced by successive approximations (Figs. 4, 5 and 6). Because of this, a CS boundary condition was never precisely produced; differential stresses vary along the left boundary by as much as a factor of two (see Figs. 4 and 5). In these models, the applied horizontal stress was approximately $0.5 \mathrm{~kb}$ in excess of the horizontal gravitationally induced stress, where

$$
\sigma_{\text {horizontal }}=(v /(1-v)) \varrho g h,
$$

and where $v=$ Poisson's ratio, $\varrho=$ density, $h=$ depth below the surface and $g=$ gravitational acceleration.

The large-basement-step models represent a different modeling philosophy from those described above in that we have exaggerated potential effects. Basement, instead of being treated explicitly, was modeled: (a) as having no vertical displacement along the horizontal interface between basement and sediments; and (b) as being fixed (no horizontal or vertical displacement) along the basement fault or slope (Fig. 3). The applied horizontal stress in this model is $0.125 \mathrm{~kb}$ in excess of the vertical gravitationally-induced stress, $\sigma_{\text {vertical }}=\varrho g h$. We have chosen a Poisson's ratio of 0.25 to maximize the effect of basement on principal stress directions. This model produced the largest stress concentrations, and thus was best suited for studying the effects of basement angularity on ramping (see Table 1 ).

\begin{tabular}{|c|c|c|c|c|c|c|c|}
\hline Model & $\begin{array}{l}\text { Sediment } \\
\text { density } \varrho \\
\left(\mathrm{g} \mathrm{cm}^{-3}\right)\end{array}$ & $\begin{array}{l}\text { Basement } \\
\text { density } \varrho \\
\left(\mathrm{g} \mathrm{cm}^{-3}\right)\end{array}$ & $\begin{array}{c}\text { Young's } \\
\text { modulus } \\
\text { sediments } E \\
\left.\text { (dyne } \mathrm{cm}^{-2}\right)\end{array}$ & $\begin{array}{c}\text { Young's } \\
\text { modulus } \\
\text { basement } E \\
\left(\text { dyne } \mathrm{cm}^{-2}\right)\end{array}$ & $\begin{array}{c}\text { Poisson's } \\
\text { ratio } \\
v\end{array}$ & $\begin{array}{l}\text { Angle of } \\
\text { basement } \\
\text { corner }\left(^{\circ}\right)\end{array}$ & Applied boundary conditions \\
\hline $\begin{array}{l}\text { No-basement- } \\
\text { step }\end{array}$ & 2.3 & 2.7 & $1.1 \times 10^{11}$ & $1.1 \times 10^{12}$ & 0.499 & 0 & $\begin{array}{l}\text { Constant displacement of } 15 \mathrm{~m} \text { in both } \\
\text { basement and sediments (CDBS). } \\
\text { Constant displacement of } 15 \mathrm{~m} \text { in sediments } \\
\text { only (CDS). } \\
\text { Constant stress in both sediments and } \\
\text { basement }(C S), 0.5 \mathrm{~kb}>(\nu /(1-v)) \text { egh }\end{array}$ \\
\hline $\begin{array}{l}\text { Small-basement- } \\
\text { step }\end{array}$ & 2.3 & 2.7 & $1.1 \times 10^{11}$ & $1.1 \times 10^{12}$ & $\begin{array}{l}0.499 \& \\
0.25\end{array}$ & 90 & As above \\
\hline $\begin{array}{l}\text { Large-basement- } \\
\text { step }\end{array}$ & 2.3 & $\begin{array}{c}\text { not } \\
\text { applicable }\end{array}$ & $1.1 \times 10^{11}$ & $\begin{array}{c}\text { not } \\
\text { applicable }\end{array}$ & 0.25 & $45 \& 90$ & $\begin{array}{l}\text { Constant stress boundary condition (CS), } \\
0.125 \mathrm{~kb}>\varrho g h\end{array}$ \\
\hline
\end{tabular}

Table 1. Model parameters 
a. CDBS

$$
\mathrm{u}=\mathbf{1 5} \mathrm{m} \text { in both layers }
$$

b. CDS

$$
u=15 \mathrm{~m} \text { in top layer }
$$

c. CS

$$
\sigma=.5 \mathrm{~kb} \text { in both layers }
$$

\section{Differential Stresses}
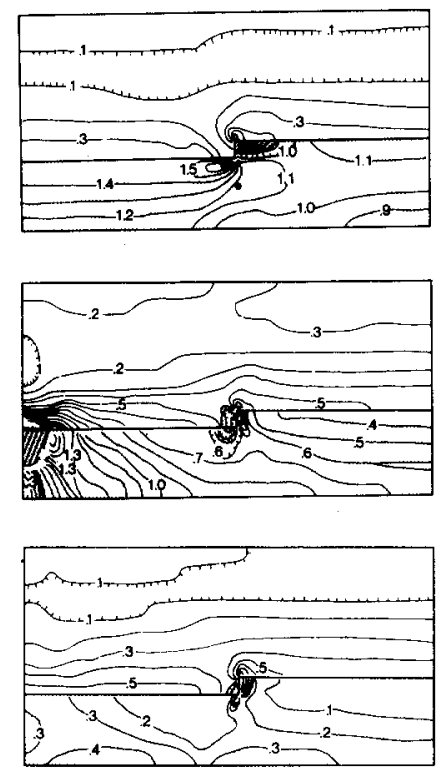

Maximum Principal Compressive Stress Directions
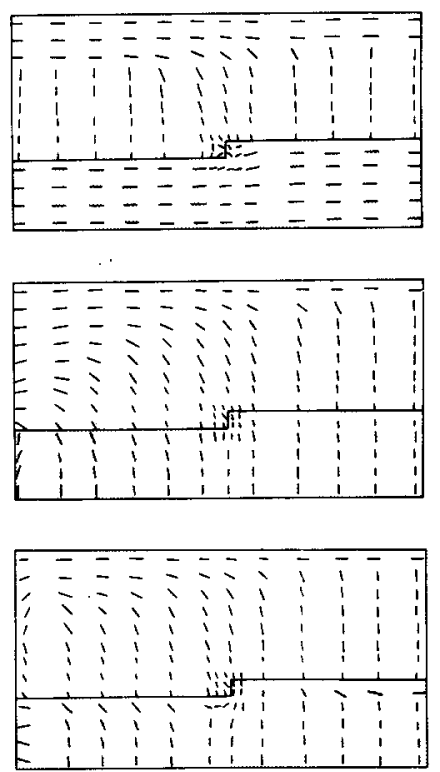

Contour Interval .1 Kilobars

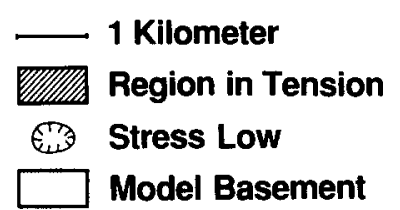

Fig. 5. Small step models, $v=0.499$. Differential stresses are contoured on the left-hand side of the figure and the corresponding maximum principal stress directions are shown on the right. (a) CDBS boundary condition; (b) CDS boundary condition; (c) CS boundary condition (see text).

\section{Material parameters}

We have chosen boundary conditions, basement geometries and material properties which bracket geologically reasonable behavior. The choices for density $(\varrho)$, Young's modulus $(E)$ and Poisson's ratio ( $v$ ) for each model are summarized in Table 1. To maximize the effect of basement on the stresses in the overlying sediments, we have chosen an order of magnitude difference in Young's modulus for basement and sediments (throughout the Methodology and Model Results sections, basement, sediments and basementsediment interface refer to our model analogues of these features). This difference, though reasonable, is rather large (see Clark 1966, Carmichael 1982). As mentioned previously, gravity was included in the models by using the equivalent nodal load formulation, in which gravity acts vertically so that $\sigma_{\text {vertical }}=\varrho g h$ (Desai \& Abel 1972). This is simulated by applying a force at each finiteelement node equivalent to the weight of the rock surrounding the node. Under the assumption of no lateral strain, this in turn generates a horizontal stress, $\sigma_{\text {horizontal }}=(v /(1-v)) \sigma_{\text {vertical }}$, and thus the Poisson's ratio determines the horizontal stresses induced by gravity.

Of the material properties used in the models, Poisson's ratio is the least well known. There are two end member choices for Poisson's ratio: (1) assume that rocks are incompressible, $v=0.5$; or (2) use the values measured in dry experiments. If rocks are incompressible, then the horizontal stress should equal the vertical stress according to $\sigma_{\text {horizontal }}=(v /(1-v)) \sigma_{\text {vertical }}$ (see Hafner 1951). In other words stresses are hydrostatic in the terminology of Jaeger (1969), $\sigma_{\text {vertical }}=\sigma_{\text {horizontal }}=$ egh. Anderson (1951) and Hafner (1951) have argued that, over the long term, a condition of hydrostatic stress is the 'standard state' for crustal rocks. This 'standard state' arises because of permanent (non-elastic) deformation (Jaeger 1969). Bedding plane stylolites, burial twins in many carbonate rocks and the loss of porosity with depth in shales indicate that stresses approach this 'standard state'. On the other hand, the in situ stress data summarized in Suppe (1985) suggest that the horizontal stress is less than the vertical gravitationally-induced stress. Gravitationally-induced differential stresses arise when $v<0.5$. Therefore, a Poisson's ratio of 0.5 must be considered to be an upper limit most applicable to 'long-term' events.

Experiments, which are a measure of short-term behavior, yield Poisson's ratios for dry rocks ranging from 0.15 to 0.25 (Clark 1962, Carmichael 1982). Most geologic modeling studies of faulting in elastic media have used these dry values (Couples 1977, Advani et al. 1978, Müller and Hsü 1980, Mandl \& Shippam 1981). 


\section{Differential Stresses}

\section{a. CDBS}

$\mathrm{u}=\mathbf{1 5} \mathrm{m}$. in both layers

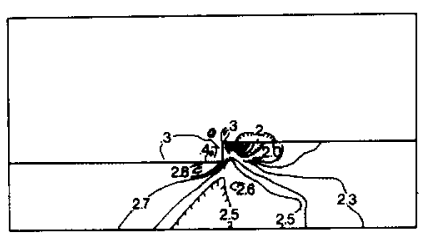

b. CDS

$$
u=15 \mathrm{~m} \text { in top layer }
$$

c. CS

$$
\sigma=.5 \mathrm{~kb} \text { in both layers }
$$
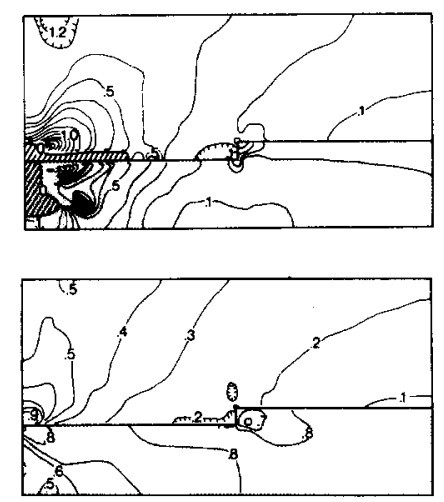

Maximum Principal Compressive Stress Directions
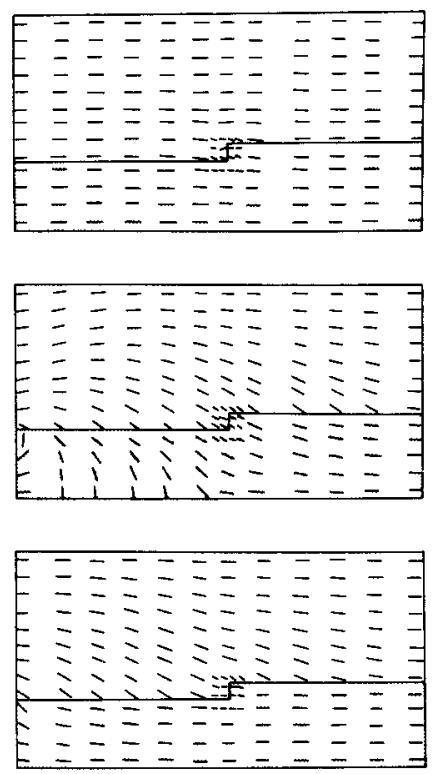

Contour Interval .1 Kilobars

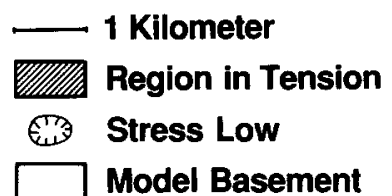

Fig. 6. Small step models, $v=0.25$. Differential stresses are contoured on the left-hand side of the figure and the corresponding maximum principal stress directions are shown on the right. (a) CDBS boundary condition; (b) CDS boundary condition; (c) CS boundary condition.

On the other hand, sedimentary rocks are generally fluid saturated. The 'effective' Poisson's ratios of fluid saturated rocks range from 0.25 to 0.41 , with a median value of 0.31 (O'Connell \& Budiansky 1974, Rice \& Cleary 1976). To bracket potential long-term and short-term behavior, we have chosen Poisson's ratios from 0.25 to 0.499 for our models (Table 1 ).

\section{MODEL RESULTS}

\section{No basement step}

For CDBS the principal stress directions are horizontal. For this same model the differential stress is $2.5 \mathrm{~kb}$ in basement and is $0.25 \mathrm{~kb}$ in sediments. The CS and CDS models have many common features. In both, stresses in the sediments die out away from the edge which received the applied stress (Fig. 4); the lowest stresses are found on the right-hand side, adjacent to the sediment-basement interface. On the other hand, stresses in the basement increase away from the applied boundary condition for the CS models. In the sediments the maximum principal stress directions dip most gently near the edge that received the applied load.

\section{Small basement step, Poisson's ratio 0.499}

The gross features of these models are similar to previous ones except in the vicinity of the basement high (Fig. 5). In all models of this type, high differential stresses are found at the corners of the step, and stresses drop off more rapidly to the right of the step, towards what would be the foreland in a geological situation, than if there had been no basement step. There is therefore a stress shadow. The stresses and their dips are only perturbed with respect to the no-topography models over a region 1-2 times the height of the topographic feature. The CS and CDS models differ from the CDBS model in that differential stresses just in front of the step in the latter model are quite small.

\section{Small basement step, Poisson's ratio 0.25}

In these models gravity generally has a greater effect on the stress field than does horizontal shortening (Fig. 6). Gravity causes differential stresses to increase with depth and principal stress directions to steepen both away from the applied load and with depth. One exception to this rule is within basement in the CDBS models (Fig. 6b), where horizontal shortening has a greater 
Stress Distribution for $45^{\circ}$ slope

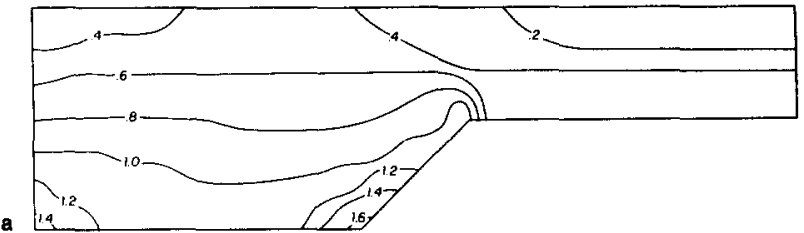

Principal Stress Directions for a $45^{\circ}$ Slope

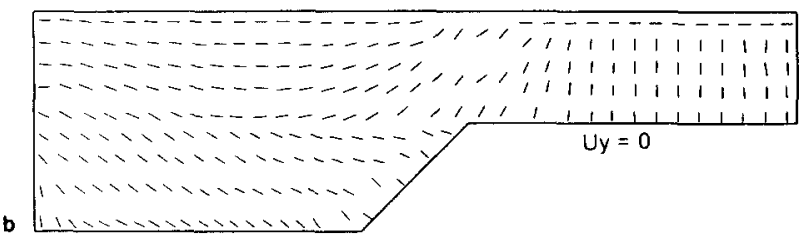

Stress Distribution for a $90^{\circ}$ Slope

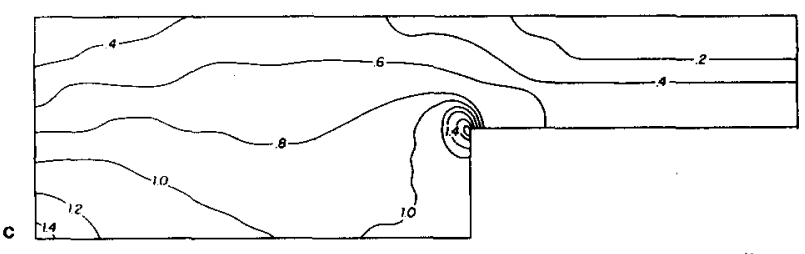

$1 \mathrm{~km}$

Contour Interval .2 KD

Fig. 7. Large basement step models, $v=0.25$ with a CS boundary condition of $0.125 \mathrm{~kb}$. (a) Contours of maximum principal stresses for the $45^{\circ}$ basement slope or basement normal fault. (b) Principal stress direction for the $45^{\circ}$ basement slope or basement normal fault. (c) Contours of maximum principal stresses for the $90^{\circ}$ basement slope or normal fault.

effect on the stress field than gravity. In this case differential stresses decrease with depth, because as depth increases gravity better counteracts the effect of the applied load. High differential stresses are again found at the corners of the basement high. Differential stresses are only perturbed over a region 1-2 times the height of the basement topographic feature.

\section{Large basement step, Poisson's ratio 0.25}

For the $45^{\circ}$ slope basement high the upper and lower corners are stress concentrators, and to the right of the basement step there is a prominent stress shadow (Fig. 7). Maximum principal stresses dip relatively gently in front of the basement feature and nearly vertically behind it. For a $90^{\circ}$ basement slope the upper corner is a stronger stress concentrator than in the $45^{\circ}$ model, and there is a more pronounced stress shadow.

\section{DISCUSSION AND APPLICATION OF MODEL RESULTS}

The no-topography CS and CDS models are similar to those of Hafner (1951) in that differential stresses die off away from the applied load and with depth (Fig. 4). If a critical stress is needed for faulting, then the region of brittle failure has a concave upward shape. In addition, if the Poisson's ratio is $<0.499$, the maximum principal
DEFORMATION PRODUCED BY A C S B C. $v=.499$

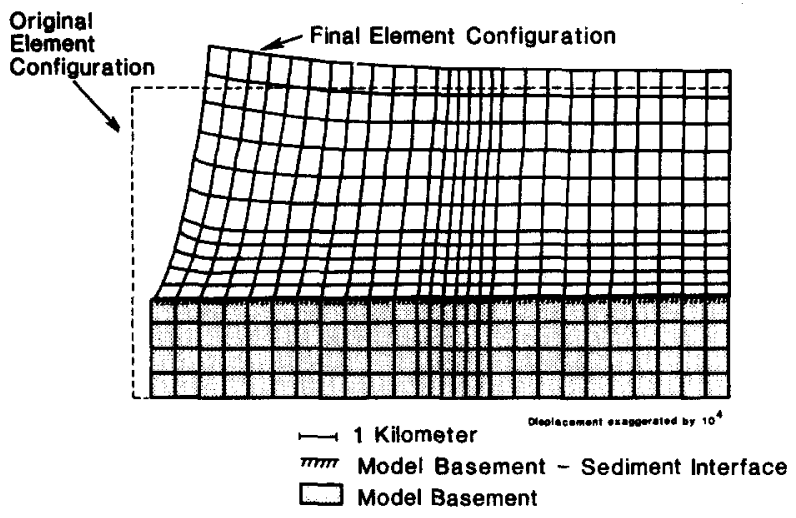

Fig. 8. The deformed finite-element grid for the no-basement-step and constant-stress boundary condition in both basement and sediments $(\mathrm{CSBC})$. Dashed lines outline the undeformed grid.

stress directions should also steepen, implying that fault trajectories steepen, as calculated from the MohrCoulomb failure envelope. The physical reason for this stress distribution is that the more rigid basement 'holds back' the overlying sediments because of the large resistance to shear along the basement-sediment interface (Fig. 8). As such, upward ramping of thrust faults need not be associated with a topographic feature, but rather be a consequence of the mechanical coupling between basement and sediments, assuming coupling is present (Fig. 9a).
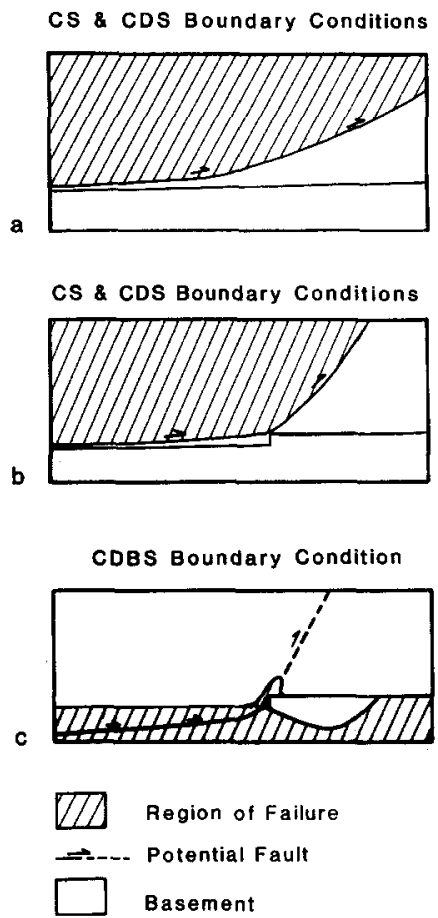

Fig. 9. Summary diagram of failure regions and potential faults for various geometries and boundary conditions. (a) In the no-basementstep model the failure region in the sediments is concave upwards for both CS and CDS boundary conditions. (b) The basement step localizes thrust faults in sediments (thin-skinned tectonics) for the CS and CDS boundary conditions. (c) The basement step localizes thrust faults in basement (thick-skinned tectonics) for the CDBS boundary condition. 
Basement topography may, however, affect the location of ramps in sediments for the CS and CDS boundary conditions by acting as a stress concentrator, by producing a stress shadow and by changing the principal stress directions. The precise effect of basement normal faults on thrust ramping can best be understood by comparing this work with Advani et al. (1978) and Wiltschko \& Eastman (1983). Aspects of each study bracket geologically reasonable behavior.

The models of Advani et al. 1978 and Wiltschko \& Eastman (1983) produce much higher stress concentrations and display regions of perturbed stresses over much larger areas than our CS and CDS models. In their models the basement normal fault is essentially a rigid boundary, whereas in our model it is allowed to deform, thus lowering the stresses at the corners. Furthermore, in our model the basement and sediments are completely coupled, whereas in theirs sediments are free to move horizontally along the basement-sediment interface. In other words, a basal décollement is presumed to exist in their models. As a result deformation piles up against the basement high in their models producing a much greater effect there. The high stresses near the basement-sediment interface in our CS and CDS models suggest that some type of basal décollement must develop. In nature, the initial basement-sediment interaction most likely lies somewhere between complete coupling and décollement. A comparison of fig. 7(a) \& (b) of Advani et al . (1978) and a careful examination of Figs. 4 and 5 in this paper suggests that a stress shadow develops behind basement normal faults. The stress shadow is more pronounced in Advani et al. (1978) for the same reasons that the stress concentration and size of the stress perturbation are greater in their models. This stress shadow is not seen in Wiltschko \& Eastman (1983), because the top surface in their model is not a free boundary condition. In both this paper (Figs. 5c, 6c and 7), and Wiltschko \& Eastman (1983) the basement normal fault is shown to alter the dips of the principal stresses; Advani et al. (1978) did not plot principal stresses for comparison. Overall, the model results of Advani et al. (1978) and Wiltschko \& Eastman (1983) suggest greater effects due to basement topography on the stress field in the overlying sediments than the models in this paper. In actuality, the models of Advani et al. (1978) and Wiltschko \& Eastman (1983), and those presented in this paper, should be viewed as end member cases.

Taking these models together, thrust faults should initially propagate from basement corners as well as along the basement-sediment interface, because differential stresses are higher there (Fig. 9b). If a critical stress is needed for faulting, the low stress region behind the basement feature should not have faults, and hence faults propagating past the basement corner should ramp upwards (Fig. 9b). For the low Poisson's ratio models the principal stress di-ections steepen above and to the right of the basement feature, the foreland side, implying (assuming a Mohr-Coulomb failure criterion) that the fault trajectories also steepen (Figs. 6 and 7). The degree to which principal stresses are reoriented is difficult to assess, because the values for Poisson's ratio are uncertain.

The effect of basement on the sedimentary package will depend on what rock type overlies it. Ratios of Young's moduli for carbonates to basement or shales to basement range from 12:1 to 2:1 (Clark 1966, Carmichael 1982). For fine to coarse indurated clastics the ratio ranges from $2.5: 1$ to $1: 1$, in which case basement and sediments would be mechanically indistinguishable. The effect of contrasting Young's modulus may in part explain why an association between thrust ramps and basement normal faults is more common in terranes where the normal faults have been active subsequent to rifting (Lille 1984). The initial rift sediments are fine to coarse clastics which, when indurated, are mechanically indistinguishable from basement. However, subsequent movement may juxtapose low Young's modulus carbonates and shales against basement.

In the models presented in this study, the stress field is only perturbed over a region 1-2 times the height of the basement feature. Consequently, only larger basement features may affect the geometry of thrust belts. The magnitude of the stress concentration is also greater for more acute basement corners, so more open corners may not produce faulting. If basement topography is to localize thrust ramps, then a critical combination of contrast of Young's modulus, height of basement topography and angularity of basement topography, is needed. One should not expect to find a one-to-one correspondence between basement topography and thrust ramps, especially because other structures such as sedimentary heterogeneities or through-faulting of preexisting folds could also produce thrust ramps (e.g. Wiltschko \& Eastman 1983).

For the CDBS boundary condition, the highest stresses are found in basement with topography again acting as a stress concentrator. This boundary condition is one mechanism for producing 'thick-skinned' tectonics with ramping to the surface from the corners of the basement warp (Fig. 9c). After faulting the CDBS boundary condition may not be strictly applicable because of both a shear and a vertical component of motion along the fault. As a consequence later faulting may be 'thin-skinned'.

As noted earlier there is some uncertainty about which Poisson's ratio to use. At the foreland edges of thrust belts the earliest maximum compressive stresses associated with thrusting are thought to be mainly horizontal (Groshong 1975, Spang \& Brown 1980, Julian \& Wiltschko 1983, Craddock \& Wiltschko 1983, Ballard \& Wiltschko 1983 , Wiltschko et al. 1985). To produce these stress orientations the Poisson's ratio should be close to 0.499 (compare Figs. 5 and 6). More refined estimates for Poisson's ratios for sedimentary rocks can be calculated from Ferguson \& Lloyd's (1982) study of boudins formed by brittle fracture under gravity loading. Using their estimates for differential stress $(\sim 500 \mathrm{~b})$ and depth of burial $(10 \mathrm{~km})$ the Poisson's ratio is 0.43 . These estimates are higher than the measurements of the 
'effective' Poisson's ratio (O'Connell \& Budiansky 1974, Rice \& Cleary 1976). Thus, even over the time scales of brittle separation of boudinage blocks or thrust fault propagation, non-elastic processes (calcite twinning or solution-redeposition) are rapid enough to give sedimentary rocks the appearance of being incompressible.

\section{CONCLUSIONS}

The interaction of basement and sediments is important in determining the geometry of thrust faults. Basement, because it is thought to be more rigid than sediments, retards the horizontal displacement of sediments producing a progressive decline in differential stresses away from the applied load. Listric thrust faults form if the differential stresses exceed the strength of the associated rocks. Basement topography also contributes to the localization and shape of thrust ramps by creating stress concentrations and stress shadows, or by reorienting the principal stress directions. However, whether basement topography localizes thrust ramps will depend upon a critical combination of the contrast in Young's moduli between basement and sediments, the amplitude of basement topography and the angularity of basement topography. The effect of contrasting Young's moduli may explain why the association between thrust ramps and rift-related basement normal faults is more common when the normal faults juxtaposed basement with carbonates and shales. In our models, whether thrusting is 'thick-skinned' or 'thin-skinned' depends on boundary conditions. Constant stress (CS) and constant displacement in sediments (CDS) produce 'thin-skinned' thrusts (Fig. 9a \& c). Constant displacement in both sediments and basement (CDBS) produce 'thick-skinned' thrusts (Fig. 9c). Our models suggest that non-elastic processes affect thrust fault propagation by making the rocks appear to be mechanically incompressible.

Acknowledgements-This research was supported by NSF grants EAR-8212714 and EAR-8406618 to DVW. Computing funds were provided by the University of Michigan computing center. We would like to thank Bill Thomas for his insights into the structural history of the Birmingham Anticlinorium, and Eric Essene, Ra Eldridge and Carola Stearns for their comments on the manuscript. Joe Bridwell made many useful suggestions on an earlier version of this paper.

\section{REFERENCES}

Advani, S. H., Ganga Rao, H. V. S., Chang, H. Y., Dean, C. S. \& Oversby, W. K. 1978. Stress trajectory simulations across the Appalachian Plateau Province in West Virginia. In: Proceedings of the First Eastern Gas Shales Symposium (edited by Shott, G., Oversby, W. K., Jr., Hunt, A. E. \& Kromar, C. A.). Morgantown Energy Research Center, Morgantown, West Virginia, 442-448.

Anderson, E. M. 1951. The Dynamics of Faulting and Dyke Formation with Applications to Britain. Oliver and Boyd, Edinburgh.

Ballard, S. \& Wiltschko, D. V. 1983. Strain directions and structural style at the northeastern end of the Powell Valley anticline, Pine Mountain block, southwestern Virginia. Geol. Soc. Am. Abs. w. Prog. 15, 520.

Bathe, K-J \& Wilson, E. L. 1976. Numerical Analysis in Finite Element Analysis. Prentice-Hall, Englewood Cliffs, New Jersey.
Carmichael, R. S. (ed.) 1982. Handbook of Physical Properties of Rocks, Vol. II. CRC Inc., Rao Raton, Florida, 290-331.

Clark, S. P., Jr. 1966. Handbook of Physical Constants. Mem. geol. Soc. Am. 97, 75-174.

Craddock, J. P. \& Wiltschko, D. V. 1983. Strain in the Prospect thrust sheet, Overthrust-belt, Wyoming. Geol. Soc. Am. Abs. w. Prog. 15, 549 .

Cummings, D. 1968. Mechanical analysis of the effect of the Timber Mountain Caldera on Basin and Range faults. J. geophys. Res. 73, 2787-2794.

Couples, G. 1977. Stress and shear fracture (fault) patterns. Pure appl. Geophys. 115, 113-134.

Desai, C. \& Abel, J. F. 1972. Introduction to the Finite Element Method: A Numerical Method for Engineering Analysis. Van Nostrand-Reinhold, New York.

Ferguson, C. C. \& Lloyd, G. E. 1982. Paleostress and strain estimates from boudinage structure and their bearing on the evolution of a Variscan fold-thrust complex, southwest England. Tectonophysics. 88, 269-289.

Groshong, R. H., Jr. 1975. Strain, fractures, and pressure solution in natural single layer folds. Bull. geol. Soc. Am. 86, 1363-1376.

Hafner, W. 1951. Stress distributions and faulting. Bull. geol. Soc. Am. 62, 373-398.

Hubbert, M. K. 1937. Theory of scale models as applied to the study of geologic structures. Bull. geol. Soc. Am. 37, 1459-1520.

Hubbert, M. K. 1951. Mechanical basis for certain familiar geologic structures. Bull. geol. Soc. Am. 62, 355-372.

Jaeger, J. C. 1969. Elasticity, Fracture and Flow with Engineering and Geological Applications. Methuen, London.

Jacobeen, F. J. Jr. \& Kanes, W. H. 1974. Structure of the Broadtop synclinorium and its implications for Appalachian structural style. Bull. Am. Ass. Petrol. Geol. 58, 362-375.

Julian, B. E. \& Wiltschko, D. V. 1983. Deformation mechanisms in a terminating thrust anticline, Sequatchie Valley anticline, Tennessee. Geol. Soc. Am. Abs. w. Prog. 15, 606.

Lille, R. J. 1984. Tectonic implications of subthrust structures revealed by seismic profiling of Appalachian-Ouachita orogenic belt. Tectonics 3, 619-646.

Lille, R. J. \& Yosuf, M. 1986. Modern analogs for some midcrustal reflections observed beneath collisional mountain belts. In: International Symposium on Deep Structure of the Continental Crust: Results from Reflection Seismology (edited by Barazangi, M. \& Brown, L.). Am. geophys. Un. geodyn. Ser. 14, 55-65.

Mandl, G. \& Shippam, G. K. 1981. Mechanical model of thrust sheet gliding and imbrication. In: Thrust and Nappe Tectonics (edited McClay, K. R. and Price, N. J.). Spec. Publs geol. Soc. Lond. 9, 79-98.

Muller, O. H. \& Pollard, D. D. 1977. The stress state near Spanish Peaks Colorado determined from a dike pattern. Pure appl. Geophys. 115, 69-86.

Müller, W. H. \& Hsü, K. J. 1980. Stress distribution in overthrusting slabs and mechanics of Jura deformation. Rock Mech. 9 (suppl.), 219-232.

O'Connell, R. J. \& Budiansky, B. 1974. Seismic velocity in dry and saturated cracked solids. J. geophys. Res. 79, 5719-5735.

Odé, H. 1957. Mechanical analysis of the dike pattern of the Spanish Peaks area, Colorado. Bull. geol. Soc. Am. 68, 567-576.

Rice, J. R. \& Cleary, M. P. 1976. Some basic stress-diffusion solutions for fluid-saturated elastic porous media with compressible constituents. Rev. geophys. Space Phys. 14, 227-241.

Sanford, A. R. 1959. Analytical and experimental study of simple geological structures. Bull. geol. Soc. Am. 70, 19-52.

SAP Technical Group, 1979. SAP6-2, A Structural Analysis Program for Static and Dynamic Analysis. U.S.C. Dept of Civil Engng, Los Angeles.

Schmidt, C. J., O'Neill, J. M. \& Brandon, W. C. 1987. Influence of Rocky Mountain foreland uplifts on the development of the frontal fold and thrust belt, southwestern Montana. In: Interaction of the Rocky Mountain Foreland Thrust Belt (edited by Schmidt, C. \& Perry, W. Jr.). Mem. geol. Soc. Am. In press.

Segall, P. 1984. Formation and growth of extensional fracture sets. Bull. geol. Soc. Am. 95, 454-462.

Seguin, M. K. 1982. Geophysics of the Quebec Appalachians. Tectonophysics. 81, 1-50.

Skipp, B. 1986. Cordilleran thrust belt and faulted foreland in the Beaverhead Mountains, Idaho and Montana. Geol. Soc. Am. Abs. w. Prog. 18, 414.

Spang, J. H. \& Brown, S. P. 1980. Dynamic analysis of a small imbricate thrust and related structures, Front Ranges, Canadian 
Rocky Mountains. In: Thrust and Nappe Tectonics (edited McClay, K. R. and Price, N. J.). Spec. Publs geol. Soc. Lond. 9, 64-77.

St. Julian, P., Slivitsky, A. \& Feininger, T. 1983. A deep structural profile across the Appalachians of southern Quebec. Mem. geol. Soc. Am. 158, 103-111.

Suppe, J. 1985. Principles of Structural Geology. Prentice-Hall, Englewood Cliffs, New Jersey.

Thomas, W. A. 1982. Stratigraphy and structure of the Appalachian fold and thrust belt in Alabama. In: Appalachian Thrust Belt in Alabama: Tectonics and Sedimentation (edited by Thomas, W. A. and Neathery, T. L.). 95th Annual Meeting geol. Soc. Am. Guidebook for Field Trip 13, 55-78.

Wiltschko, D. V. \& Eastman, D. B. 1983. Role of basement warps and faults in localizing thrust fault ramps. Mem. geol. Soc. Am. 158, 177-190.

Wiltschko, D. V., Medwedeff, D. \& Millson, H. 1985. Distribution and mechanisms of strain within rocks of the northwest ramp of Pine Mountain block, southern Appalachian foreland: a field test of theory. Bull. geol. Soc. Am. 96, 426-435.

Zienkiewicz, O. C. 1977. The Finite Element Method. McGraw-Hill, London. 